\title{
Design and Experimental Study on Seed Metering Device of Peanut Plot Seeder
}

\author{
Wang Dongwei, \\ professor; \\ Wang Jiasheng;
}

\author{
Shang Shuqi, \\ professor, e-mail: jiasheng0813@163.com
}

College of Mechanical and Electrical Engineering, Qingdao Agricultural University, Qingdao, China

\begin{abstract}
The seed metering device is the key working part of the peanut planter and is placed above the bottom of the seed box or above the opener. The essence of the seed metering process is the effect of the seed meter on the seed, converting the seed from the population into an individual, and converting it into a uniform seed stream or a continuous single seed. The seeding method and quality of the seeding machine depend mainly on the seed metering device. Aiming at the shortage of re-broadcasting rate and missed-out rate during sowing, the different parameters of the air-suction metering device were analyzed, and the seeding performance of the seeding device was tested to obtain the primary and secondary factors affecting the performance of the seeding device, and the quality of seeding was improved.
\end{abstract}

Keywords: peanut; sowing, air suction type seed metering, seed quality.

IFor citation: Dongwei W., Jiasheng W., Shuqi S. Design and experimental study on seed metering device of peanut plot seeder. Sel'skokhozyaystvennye mashiny i tekhnologii. 2019. Vol. 13. N4. 38-41 (In English). DOI 10.22314/20737599-2019-13-4-38-41.

\section{Конструктивно-экспериментальный расчет дозатора семян арахиса в селекционной сеялке}

\section{Ван Донгвей, профессор;}

Ван Цзяшэн;

\author{
Шан Шуки, \\ професcop, e-mail: jiasheng0813@163.com
}

Колледж механики и электротехники, Сельскохозяйственный университет Циндао, Циндао, Китай

Реферат. Дозатор семян считается ключевым рабочим органом сеялки арахиса. Он расположен над дном семенного ящика или над сошником. Суть процесса дозирования семян заключается в воздействии дозатора с целью выделения отдельных семян из массы и направления их непрерывным потоком. Способ посева и качество сеялки зависят в основном от работы дозатора семян. Проанализировали параметры пневматического дозирующего устройства, улучшение которых поможет нивелировать такие недостатки, как медленная скорость, сдваивание или пропуски семян при посеве. Определили факторы, влияющие на производительность высевающего аппарата. Провели необходимые расчеты оптимальных критериев, чтобы улучшить качество посева.

Ключевые слова: арахис; посев; пневматическое дозирование семян; качество семян.

$\mathrm{P}$ eanut is one of the four major oil crops in China. It is an important economic crop and a protein plant with high nutritional value. It plays an important role in world agricultural production $[1,2]$. The yield, total output and export volume of peanuts in China rank first among the world's major peanut producers in the same period [3]. It is grown all over China, mainly in Liaoning, Shandong, Hebei, Henan, Jiangsu, Fujian, Guangdong, Guangxi, Sichuan, Jilin and other provinces. Among them, Shandong Province has the largest planting area and the largest output. With the continuous development of agricultural science and technology, it is constantly developing towards precision agriculture.

Sowing and harvesting is the most time-consuming part of the peanut production process. The outstanding problem at this stage is that the variety of peanut seeding machinery, performance and quality can not fully meet the requirements [4]. The development of planters has accelerated the pace of mechanized agricultural production, liberated the labor force and promoted economic devel- 
opment. At present, the mechanization level of peanut planters in China is still different from that in developed countries. Therefore, the development of efficient peanut seeding machinery is becoming more and more important.

Seeding largely determines the quality of the sowing, and the key component of the planter is the design of the seed meter. As an important form of pneumatic precision seed metering device, the air suction type metering device mainly includes horizontal disc type, vertical disc type and combined suction type. At present, the use of peanut seeding devices in China is less used for air suction type seeding devices, and foreign countries have made great progress. The air suction type metering device has strict requirements on seed size, good versatility, high seeding precision, and is suitable for high speed operation. In China, for high-speed operation, the influence of the vacuum degree of the suction chamber of the metering device, the diameter of the suction hole, the rotation speed of the seeding tray, etc., cannot be well designed to design an effective air suction metering device for Precision seeding. Therefore, this paper focuses on the problem and conducts experimental research on the technical parameters of its key components.

\section{Theoretical analysis of the seed meter}

1.1 Establishment of vacuum degree of air suction type metering device

The performance of the metering device depends on the suction vacuum degree. The greater the degree of vacuum, the stronger the ability of the suction hole to adsorb the seed, and it is not easy to cause leakage. However, if the degree of vacuum is too large, the possibility of adsorbing multiple seeds by one suction hole is increased, and replay is generated. In the actual seeding process, the seed meter is affected by the external factors of the seed and the stability coefficient of the work. The maximum value of the vacuum required for the vacuum chamber of the air suction meter is calculated [5].

$$
H_{c \max }=\frac{80 k_{1} k_{2} m g c}{\pi d^{3}}\left(1+\frac{v^{2}}{g R}+\lambda\right),
$$

where: $H_{\mathrm{cmax}}$ - the maximum vacuum of the suction chamber, $\mathrm{kPa}$;

$d$ - row of seed hole diameter, $\mathrm{cm}$;

$c$ - the distance between the center of gravity of the seed and the suction tray, cm;

$m$ - the quality of a seed, $\mathrm{kg}$;

$v$ - the linear velocity at the center of the suction hole of the seed disc, $\mathrm{m} / \mathrm{s}$;

$R$ - the radius of rotation of the suction hole of the seed disc, $\mathrm{m}$;

$g-$ gravity acceleration, $\mathrm{m} / \mathrm{s}^{2}$

$\lambda-$ a comprehensive friction coefficient of friction, $\lambda=(6 \sim 10) \tan \alpha, \alpha$ is the natural angle of repose of the seed;

$k_{1}$ - a species reliability coefficient, taking $1.8 \sim 2.0$, when the seed 1000-grain weight is small and the shape is approximately spherical, take a small value;

$k_{2}$ - the external condition coefficient, which is 1.6 2.0. When the seed dry grain is large, take a large value.

It can be known from formula (1) that the maximum vacuum degree required for the air suction type seed meter and the diameter of the suction hole and the line speed level at the center of the suction hole are physically special.

For different seeds, there is an optimum vacuum range. When the vacuum is reduced, the leak rate will increase, and when the vacuum is too large, the reciprocity will increase. In actual work, due to the influence of pipeline pressure loss and mechanical vibration between the fan and the metering device, the maximum degree of vacuum is taken during design.

1.2 Determination of seed force of air suction metering device

When the seed moves on the seed ring, it will exert a force. When the seed meter works, if the friction is neglected, the seed is mainly subjected to the force of gravity $G$, the adsorption force $F$, the inertial force $J$ and the support force of the suction hole to the seed. The role. According to the literature [6], the formula of the adsorption force $F$ and the inertial force $J$ is

$$
\begin{aligned}
& F=\frac{\pi d^{2}\left(p_{a}-p_{1}\right)}{4} ; \\
& J=m R / \omega^{2},
\end{aligned}
$$

were: $p_{\mathrm{a}}-$ atmospheric pressure, $\mathrm{Pa}$;

$p_{1}$ - vacuum chamber pressure, $\mathrm{Pa}$;

$d$-sucking hole diameter, $\mathrm{m}$;

$m$ - seed quality, kg;

$R$ - the distance from the center of gravity of the seed to the center of the seed tray, $m$;

$\omega$ - the angular velocity of the seeding $\mathrm{ring}, \mathrm{rad} / \mathrm{s}$.

In order for the suction hole to suck the seed, the following conditions should be met.

$F d / 2 \geq T h$,

where: $T$ - the resultant force of gravity $G$ and inertial force $J, N$

$h-T$ to the distance of the suction ring, $\mathrm{m}$.

1.3 metering device housing

The seed meter housing is used to closely cooperate with the seeding ring to form a vacuum chamber, and the device has a device such as a friction reducing device, a sealing device and an air suction pipe interface. The casing and the seed ring are sealed with a wear-reducing seal to prevent air leakage. The suction pipe joint is tightly connected to the casing, and is closely connected with the fan by a rubber pipe to provide vacuum pressure to the seed meter. A pulley is arranged in a section of the outer casing, and is driven by a gearbox to provide power to drive the rotation of the seeding ring for seeding.

\section{4 type of hole movement speed}

In order to ensure the quality of the seeding, the re- 
quirements for the filling of the holes are achieved. For the requirement of filling empty, according to the size of different peanut varieties, the suitable hole filling requirement is found, and the filling time is determined according to the linear velocity of the upper hole of the seed ring. The seed filling process and the accuracy of seeding are determined by the line speed at the hole. If the line speed is too high, when the seed chamber passes through the hole, the time for the seed to enter the hole is shortened, and the seed is not filled in time. Into the type of hole in the seed ring, it will cause leakage. For the filling condition of the seed, from the kinematic point of view, the seed should be filled into the pore in a limited time, and the excess seed can be removed by the seed cleaning device to ensure the precision of the seeding. Depending on the line speed of the hole, the seed enters the hole by gravity. Therefore, according to the free fall motion equation, the ultimate speed of peanut seeds during the filling process can be obtained.

If there is no device that assists in increasing the filling ability, when the line speed exceeds the limit speed of the hole, the filling ability is lowered. In the actual process, the seed meter is driven by the ground wheel, and the ground wheel is powered by the tractor's traction, so the forward speed of the tractor affects the linear speed of the hole. Through the kinematics formula, the forward speed of the tractor is directly proportional to the linear velocity of the hole. The diameter of the seeding ring and the number of holes in the seeding ring affect the speed of the hole. When the linear velocity of the hole is reduced, the diameter of the seed ring and the number of the hole are reduced, the distance between the holes is shortened, and interference occurs between the seeds when the seed is filled, and the diameter of the larger seed ring can be Increasing the irrigating distance and filling time greatly improves the ability to replenish.

\section{Structure design of the seed meter}

\subsection{Structure and principle of the seed meter}

The air suction type seed meter is mainly composed of a seeding device, a vacuum chamber, an air suction pipe, a seed cleaning device, a seed room and the like. The seed meter uses a fan to generate a negative pressure for seeding, has a good filling ability, and can operate at a high speed (Fig. 1).

The vacuum chamber of the metering device is connected to the fan suction port to generate a negative pressure in the vacuum chamber.

The seed chamber is connected with the seed ring, relies on the negative pressure generated inside, sucks the seed through the small hole, and uses the transmission system to rotate along with the seed ring. When the seed is transferred out of the vacuum chamber, it is not subjected to negative pressure. The weight or the pusher drops into the seed groove. The seed cleaning device in the upper part of the seed ring removes excess seeds from the suction holes.

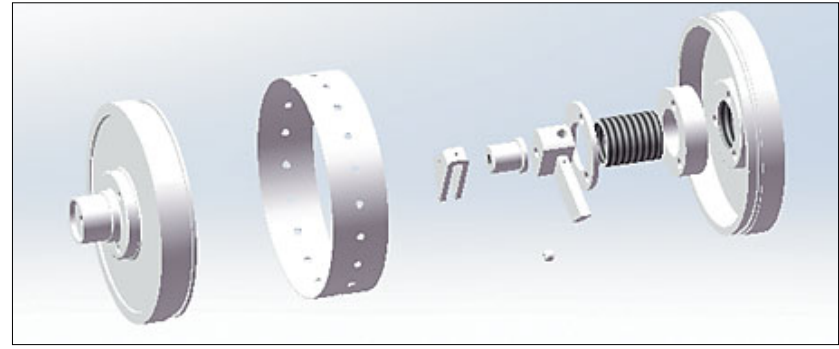

Fig. 1. Rower structure diagram

\subsection{Design of the seed ring}

The seeding ring is the core component of the air suction type metering device, and determining the reasonable structural parameters of the seeding ring is an important condition for ensuring the quality of the seeding. The size of the seed hole affects the performance of the seed meter. As the area of the pore increases, the pressure required for the adsorption of the seed is reduced, the degree of vacuum is reduced, and the seeding performance is gradually increased. When the suction hole is increased to a certain extent, the gas leakage is generated due to the excessive pore size. Decrease, the seeding performance is reduced. The suction hole is too small, and the adsorption force on the seed is insufficient, which may cause leakage. Therefore, the size of the suction hole should be

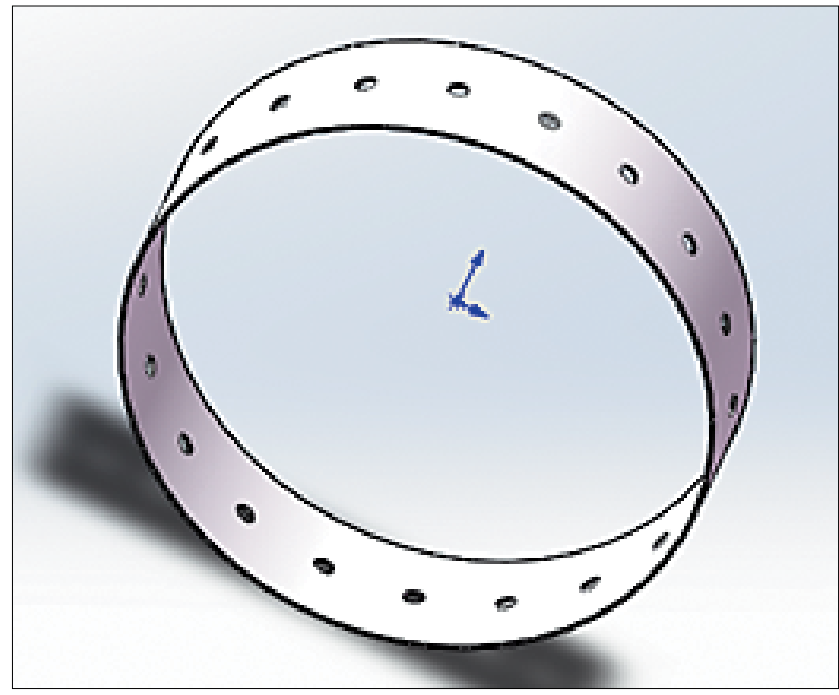

Fig. 2. Seeding ring

designed according to the seed size (Fig. 2).

The number of seed holes also affects the performance of the seed meter. In the case that the number of the seeding holes does not affect the seed filling, seeding, and this parameter is increased as much as possible. As the number of seeding holes increases, the rotation speed of the seeding ring decreases, the filling time is longer, and the seeding performance is gradually increased. As the number of seeding holes increases, the distance between the two holes gradually decreases. After the number of seed holes is increased to a certain extent, the two suction holes cause interference when the seeds are sucked, which causes the seeds 
to be confused and the seeding performance is lowered.

The rotation speed of the seed ring is an important factor affecting the seeding. When the rotation speed of the seeding ring is increased, the seeding ability can be improved and the seeding can be accelerated. However, when the rotational speed reaches a certain level, the seed may not be sucked up or the seed may collide, causing the seed to fall off and causing leakage. When the degree of vacuum reaches a certain level, it is difficult to increase at the limit rotation speed, causing difficulty in seeding. A reasonable vacuum should be found within the limit speed range to achieve optimum seeding.

\subsection{Seeding device}

The air suction type seed meter is externally loaded, and the seed chamber is filled on the outside of the seed meter. When the seeding ring rotates and carries the seed through the clearing brush, the excess seed is scraped off and the seed falls to the seed chamber. The seed chamber is spliced by several plastic plates and nested on the seeding ring, and is filled by contacting the seed ring with a felt gasket.

\subsection{Cleaning methods}

The seed cleaning device is an important device for the seed metering device to achieve precise seeding. For the seeding and seeding device, when the seed enters the suction hole for seeding, it may carry excess seeds to cause replay, so it is necessary to design a seed cleaning device to achieve precise seeding. At present, there are many kinds of cleaning devices applied to the seed metering device, such as the scraper type and the brush wheel type seed cleaner, which are suitable for the seeding device in the form of horizontal orifice plate and socket wheel [7]. The squeegee or brush wheel needs to have a spring to maintain a certain elasticity to avoid injury and possibly remove excess seeds. The brush wheel uses its own rotation to brush away excess seeds with the rim. When the air suction type seeding device is broadcasting peanuts,

\begin{tabular}{|l|c|c|c|}
\hline \multicolumn{4}{|c|}{ TEST PERFORMANCE INDEX OF AIR SUCTION TYPE METERING DEVICE } \\
\hline \multicolumn{1}{|c|}{ Project } & $\begin{array}{c}\text { Missing } \\
\text { rate, } \%\end{array}$ & $\begin{array}{c}\text { Replay } \\
\text { rate, \% }\end{array}$ & $\begin{array}{c}\text { Breakage } \\
\text { rate, \% }\end{array}$ \\
\hline Skills requirement & $\leq 8$ & $\leq 8$ & $\leq 10$ \\
\hline Test results & 0.6 & 0.8 & 1.0 \\
\hline
\end{tabular}

the cleaning device must not damage the peanut seed coat. Therefore, the soft material brush is used for seed cleaning, and the airflow can be used for seed cleaning.

\section{Peanut seed meter performance test}

3.1 Basic conditions of the test

The peanut seeds used in the experiment were Huashi No. 2. This variety is a new line of high-yield and high-quality traditional large peanuts. The leaves are elliptical, with 19 results per plant and 15 fruit numbers. The pod has a common shape, and the seed is long and elliptical. The rice yield is $76.1 \%$, the fruit weight is $223 \mathrm{~g}$, and the kernel weight is $97.1 \mathrm{~g}$.

\subsection{Test results}

The technical performance indicators of the seed metering device meet the design requirements and relevant technical standards (Table).

\section{Conclusion}

1. The design of the peanut seed meter is an important part of the seeding.

2. Analysis of the leakage rate and re-broadcast rate of peanut seeding, mainly due to factors such as the rotation speed of the seed ring, the structure of the seed meter, the vacuum degree of the vacuum chamber, and the pore size. In this paper, the test parameters of the seed meter are optimized, and the key data of the seed meter is analyzed.

3. The seed meter effectively solves the missed broadcast rate and the replay rate, and improves the efficiency of precision seeding.

\section{REFERENCES}

1. Rongdong $\mathrm{Zh}$. The development of peanut harvesting machinery is imminent. Agricultural Machinery. 2004. 9(4). 4-5 (In English).

2. Yuhua W. Research on the Development Strategy of Agricultural Mechanization in China. Beijing: China Agricultural Press. 2008. 126-131 (In English).

3. Xiumei J. Design of 2BHQ-2 Air-suction Peanut Precision Planter.农业机械, 2012. 2(8). 97-99 (In Chinese).

4. Xuan L. Design and experiment of the filling type seeding device on the inside of peanut seeder. Transactions of the Chi-

Конфликт интересов. Авторы заявляют об отсутствии конфликта интересов.

Статья поступила в редакцию 05.08.2019 The paper was submitted to the Editorial Office on 05.08.2019 nese Society of Agricultural Engineering. 2014. 10(28). 47-51 (In English).

5. China Agricultural Machinery Research Institute. Practical Mechanical Design Manual (I). Beijing: Mechanical Industry Press. 1998 (In English).

6. Boping Zh. Modern Planting Machinery Engineering. Beijing: Mechanical Industry Press, 1997 (In English).

7. Qiang Zh. Agricultural Machinery. Jilin: Chemical Industry Press. 2016 (In English).

Conflict of interest. The authors declare no conflict of interest.

Статья принята к публикации 02.09.2019 The paper was accepted for publication on 02.09.2019 